University of Nebraska - Lincoln

DigitalCommons@University of Nebraska - Lincoln

Cytogenetic and Nuclear DNA Content Characterization of Diploid Bromus erectus and Bromus variegatus

\author{
Metin Tuna \\ University of Trakya \\ Kenneth P. Vogel \\ University of Nebraska-Lincoln, kvogel1@unl.edu \\ K. Arumuganathan \\ Benaroya Research Institute
}

Follow this and additional works at: https://digitalcommons.unl.edu/usdaarsfacpub

Tuna, Metin; Vogel, Kenneth P.; and Arumuganathan, K., "Cytogenetic and Nuclear DNA Content Characterization of Diploid Bromus erectus and Bromus variegatus" (2006). Publications from USDA-ARS / UNL Faculty. 1947.

https://digitalcommons.unl.edu/usdaarsfacpub/1947

This Article is brought to you for free and open access by the U.S. Department of Agriculture: Agricultural Research Service, Lincoln, Nebraska at DigitalCommons@University of Nebraska - Lincoln. It has been accepted for inclusion in Publications from USDA-ARS / UNL Faculty by an authorized administrator of DigitalCommons@University of Nebraska - Lincoln. 


\title{
Cytogenetic and Nuclear DNA Content Characterization of Diploid Bromus erectus and Bromus variegatus
}

\author{
Metin Tuna, Kenneth P. Vogel,* and K. Arumuganathan
}

\begin{abstract}
Bromus erectus Huds. (erect brome) and B. variegatus M. Bieb. are Eurasian Bromus species that have been tentatively identified as potential progenitors of smooth bromegrass $(B$. inermis Leyss) which is the principal cultivated bromegrass in North America. The objective of this study was to characterize the genome of diploid accessions of $B$. erectus $(2 n=2 x=14)$ and $B$. variegatus $(2 n=2 x=14)$ using nuclear DNA content and cytogenetic analysis using Giemsa Cbanding. The nuclear DNA content for $B$. erectus $(6.19 \pm 0.08 \mathrm{pg}$ $\left.2 C^{-1}\right)$ was less than that of $B$. variegatus $\left(6.76 \pm 0.05 \mathrm{pg}^{-1}\right)$. These two species can be distinguished cytogenetically with the karyotypes that were developed. Complete karyotypes were not developed for both species because within species, multiple chromosomes were similar in size and C-banding. Both species had two pairs of chromosomes with satellites but the size of the satellites and the number and position of C-bands on these chromosomes differed between species. Bromus variegatus had five pairs of chromosomes with telomeric C-bands on both arms, while $B$. erectus had four pairs of chromosomes with a single telomeric band on the long arm and a single pair with telomeric bands on both arms. Comparison with the previously reported karyotypes and nuclear DNA contents for tetraploid and octaploid $B$. inermis suggest that if the diploid species $B$. erectus and $B$. variegatus were the donor species for these polyploids, significant evolutionary changes have occurred since the initial formation of these species including chromosome loss and re-arrangement.
\end{abstract}

$\mathrm{T}$ HE GENUS Bromus L. contains more than 100 species of grasses with wide geographic distribution and is divided taxonomically into several sections (Armstrong, 1991). The largest section, Pnigma, consists of approximately 60 species that are found in western to eastern Eurasia and North and South America (Armstrong, 1991). Important cultivated species of the section Pnigma are smooth bromegrass, $B$. inermis, and meadow bromegrass, B. riparius Rehm (Vogel et al., 1996). There are tetraploid $(2 n=4 x=28)$ and octaploid $(2 n=8 x=$ 56) cytotypes of smooth bromegrass (Vogel et al., 1996; Tuna et al., 2001b). The decaploid B. riparius $(2 n=$ $10 x=70)$ is believed to contain the same genomes as octaploid B. inermis plus an additional genome (Armstrong, 1991). The genomic structure and the source of

M. Tuna Department of Agronomy, Tekirdag Faculty of Agriculture, University of Trakya, Tekirdag, Turkey; K.P. Vogel, USDA-ARS, Wheat, Sorghum, and Forage Research. Unit, 344 Keim Hall, University of Nebraska, P.O. Box 830937, Lincoln, NE 68507-0937; K. Arumuganathan, formerly at Center for Biotechnology, University of Nebraska, Lincoln, NE 68588, now at Virginia Mason Research Center, Benaroya Research Institute, 1201 Ninth Avenue, Seattle, WA 98101, USA. Received 2 Mar. 2005.*Corresponding author (kpv@unlserve.unl.edu).

Published in Crop Sci. 46:637-641 (2006).

Crop Breeding, Genetics \& Cytology

doi:10.2135/cropsci2005.0178

(C) Crop Science Society of America

677 S. Segoe Rd., Madison, WI 53711 USA the genomes of these important forage grasses has not been completely resolved.

Previous studies reviewed by Armstrong (1991) and Vogel et al. (1996) supported the hypothesis that the genomic formulas for tetraploid and octaploid smooth bromegrasses are AABB and AAAABBBB. However, a recent cytogenetic study by Tuna et al. (2004) using Geimsa C-banding analyses indicates that the octaploid of $B$. inermis is probably not a doubled form of tetraploid $B$. inermis. The B genome is believed to be closely related to the A genome (Armstrong, 1991). According to research conducted and interpreted by Armstrong (1977, 1979, 1991) tetraploids of $B$. erectus (AAAA) contain a form of the A genome as does $B$. variegatus $(2 n=2 x=14)$. In another cytogenetic study in which hybrid progeny of crosses between diploid $B$. variegatus and tetraploid and octaploid $B$. inermis were evaluated, chromosome pairing results indicated that the $B$. variegatus genome was differentiated from both the $\mathrm{A}$ and $\mathrm{B}$ genomes of $B$. inermis but was more closely related to them than they were to each other (Armstrong, 1984). Armstrong (1991) reported that the $F_{1}$ hybrid of diploid $B$. variegatus by diploid $B$. riparius had been produced and that the hybrids were sterile but had regular chromosome pairing.

Feulgen-based karyotypes have been constructed for some species of the genus Bromus (Rychlewski, 1970; Armstrong, 1977) but it has been difficult to characterize many Bromus species cytologically because the chromosomes are similar in morphology. Giemsa C-banding technique, which stains constitutive heterochromatin, is a technique that has been used successfully in many species to identify individual chromosomes and to establish genomic relationships among species (Fominaya et al., 1988; Gill and Sears, 1988; Falistocco et al., 1995). We have used C-banding analyses to characterize the genome of the diploid $B$. riparius and tetraploid B. ciliatus L. $(2 n=4 x=28)$ and developed complete karyotypes for these species (Tuna et al., 2001a, 2005). Based on C-banding analyses, B. ciliatus is an allotetraploid but no genome designations were made. We have also applied C-banding cytogenetic analyses to tetraploid and octaploid B. inermis (Tuna et al., 2004). More definitive karyotypes of $B$. inermis were obtained than previously available for these species but it was not possible to completely differentiate all the chromosomes for both tetraploid and octaploid B. inermis. In addition, we also have characterized the genome size of these species by nuclear DNA content using flow cytometry analyses (Tuna et al., 2001b, 2005).

Abbreviations: pg 2C $\mathrm{C}^{-1}$, DNA content of a diploid somatic nucleus in picograms. 
The first objective of this study was to characterize the genome of diploid accessions of $B$. erectus and $B$. variagatus using nuclear DNA content and Geimsa Cbanding cytogenetic analyses. The second objective was to compare these C-banded karyotypes and DNA content information of these species to those of diploid $B$. riparius, tetraploid $B$. ciliatus, and tetraploid and octaploid B. inermis.

\section{MATERIALS AND METHODS}

Seeds of B. erectus (PGR 4448) were obtained from Plant Gene Resources of Canada, Saskatoon, SK S7N 0X2. Seeds of B. variagatus (PI 315395) were obtained from the United States Department of Agriculture's (USDA) National Plant Germplasm System (http://www.ars-grin.gov/npgs/) via the USDA Regional Plant Introduction Station, Pullman, WA. Seeds were placed in germination boxes containing germination paper saturated with distilled water. For flow cytometric analysis, 20 seedlings for each accession were transferred to pots filled with a mixture of 2:1:1 soil/perlite/peat moss. The plants were grown in a greenhouse and exposed to 16-h photoperiod. They were maintained in a vegetative stage by clipping.

Nuclear DNA content of 10 individual plants for each accession was determined using flow cytometry at the University of Nebraska Flow Cytometry Core Research Facility [FACScan flow cytometer (Becton Dickinson Immunocytometry system, San Jose, CA)]. Diploid barley (Hordeum vulgare L. cv. Hitchcock) was used as standard. Nuclear DNA values are expressed in picograms as "C" values (Bennett and Smith, 1976). The letter C stands for "constant" or the DNA in a haploid nucleus or genome; $2 \mathrm{C}$ values reported in this paper, represent the DNA content of a diploid somatic nucleus. For diploid barley, the 2C complement of DNA per nucleus is $10.68 \mathrm{pg}$. The flow cytometry methods are described in detail by Tuna et al. (2001b). A simple statistical procedure using confidence intervals was used to test if the nuclear DNA content of the species differed (Vogel et al., 1999). A confidence interval was calculated for each mean (Steel and Torrie, 1960). If the confidence intervals for DNA content of two species did not overlap, they were considered to be significantly different. This test is equivalent to a simple $t$ test (Steel and Torrie, 1960).

For cytological investigations, imbibed seeds in a germination box were kept at room temperature for $1 \mathrm{~d}$ before they were transferred to a refrigerator at 0 to $4{ }^{\circ} \mathrm{C}$ for one to several days (until the majority of seeds appeared to be germinating). The seeds were then placed in the dark at room temperature and fast-growing root tips were collected when they reached 1 to $1.5 \mathrm{~cm}$ in length. Harvested root tips were treated with $0.05 \%$ colchicine $(\mathrm{w} / \mathrm{v})$ for 1 to $2 \mathrm{~h}$ and stored in a fixative of 3:1 ethanol/glacial acetic acid for at least $2 \mathrm{wk}$ before making preparations. Techniques for chromosome squash preparations and C-banding are described by Tuna et al. (2001a). Cells with well-spread chromosomes were identified and an image of each cell was captured by a Spot I digital camera (Diagnostic Instruments Inc., Sterling Heights, MI). Printed enlarged pictures $(3000 \times)$ of 10 cells from 10 different plants with well-spread metaphase chromosomes were used for analysis and construction of karyotypes.

Chromosome measurements were made on the enlarged prints with a ruler and converted to microns by relating measurements from enlarged prints with measurements made in a microscope with a micrometer. The chromosomes were identified on the basis of their total length, arm ratio, C-banding patterns, and presence or absence of satellites.

\section{RESULTS}

The $B$. erectus and $B$. variegatus accessions were verified to be diploids $(2 n=2 x=14)$. The nuclear DNA content of $B$. erectus is significantly smaller $(P=0.05)$ than that of $B$. variegatus and is equivalent to the nuclear DNA content of the diploid B. riparius (Table 1). Diploid B. variegatus and diploid B. riparius differ in nuclear DNA content $(P=0.05)$.

All chromosomes of diploid B. erectus were metacentric with the arm ratios ranging from 1.03 to 1.11 (Fig. 1, Table 2). Two pairs of chromosomes had satellites. One pair had a small satellite with a telomeric band. The other pair had a large satellite with a terminal C-band and an interstitial band on the short arm. Chromosomes with satellites also had a C-band at the nucleoulus organizer region site on the chromosome and a C-band adjacent to the satellite. Two pairs of chromosomes had telomeric bands on both arms and five pairs of chromosomes had a telomeric band on only one arm. Chromosomes ranged in length between approximately 6.29 and $8.19 \mu \mathrm{m}$. The total haploid genome length was determined as $49.61 \mu \mathrm{m}$.

It was not possible to identify all homologous chromosomes by chromosome morphology and C-banding patterns due to similarity of eight chromosomes. Based on chromosome morphology and C-banding patterns, we were able to group the diploid B. erectus chromosomes into four sets (Fig. 1, Table 2). One set (I) has eight metacentric chromosomes with a single telomeric band; set II has a pair of chromosomes with telomeric bands on both arms; set III has a pair of chromosomes with a large satellite, telomeric bands on both arms, and an interstitial band; set IV has a pair of chromosomes with a small satellite with a telomeric band.

All of the diploid B. variegatus chromosomes had large telomeric bands on both arms except two pairs of satellite chromosomes (Fig. 2, Table 3). All chromosomes were metacentric with arm ratios ranging from 1.08 to 1.13. Satellite chromosomes had telomeric bands on only one arm which is the arm carrying the satellite. The two pairs of chromosomes with satellites could be distinguished from each other by satellite size and the number of C-bands on the arm carrying the satellite. Chromosomes with satellites also had a C-band at the nucleoulus organizer region site on the chromosome. Chromosomes ranged in length between approximately 7.83 and $7.45 \mu \mathrm{m}$ (Table 3). The total haploid genome length was determined as $54.3 \mu \mathrm{m}$. It was not possible to separate the nonsatellite chromosomes into distinct pairs because of the similarity in size, morphology, and C-banding patterns. All

Table 1. Nuclear DNA content of diploid bromegrass species.

\begin{tabular}{lccc}
\hline Species & Chromosome number & Mean DNA content & SD \\
\hline & $2 n$ & $\operatorname{pg~2C}^{-1} \dagger$ & \\
B. erectus & 14 & 6.19 & 0.08 \\
B. variegatus & 14 & 6.76 & 0.05 \\
B. riparius & 14 & $6.14 \ddagger$ & 0.09 \\
\hline
\end{tabular}

$\dagger$ pg $2 \mathrm{C}^{-1}$, DNA content of a diploid somatic nucleus in picograms.

From Tuna et al. (2001b). 

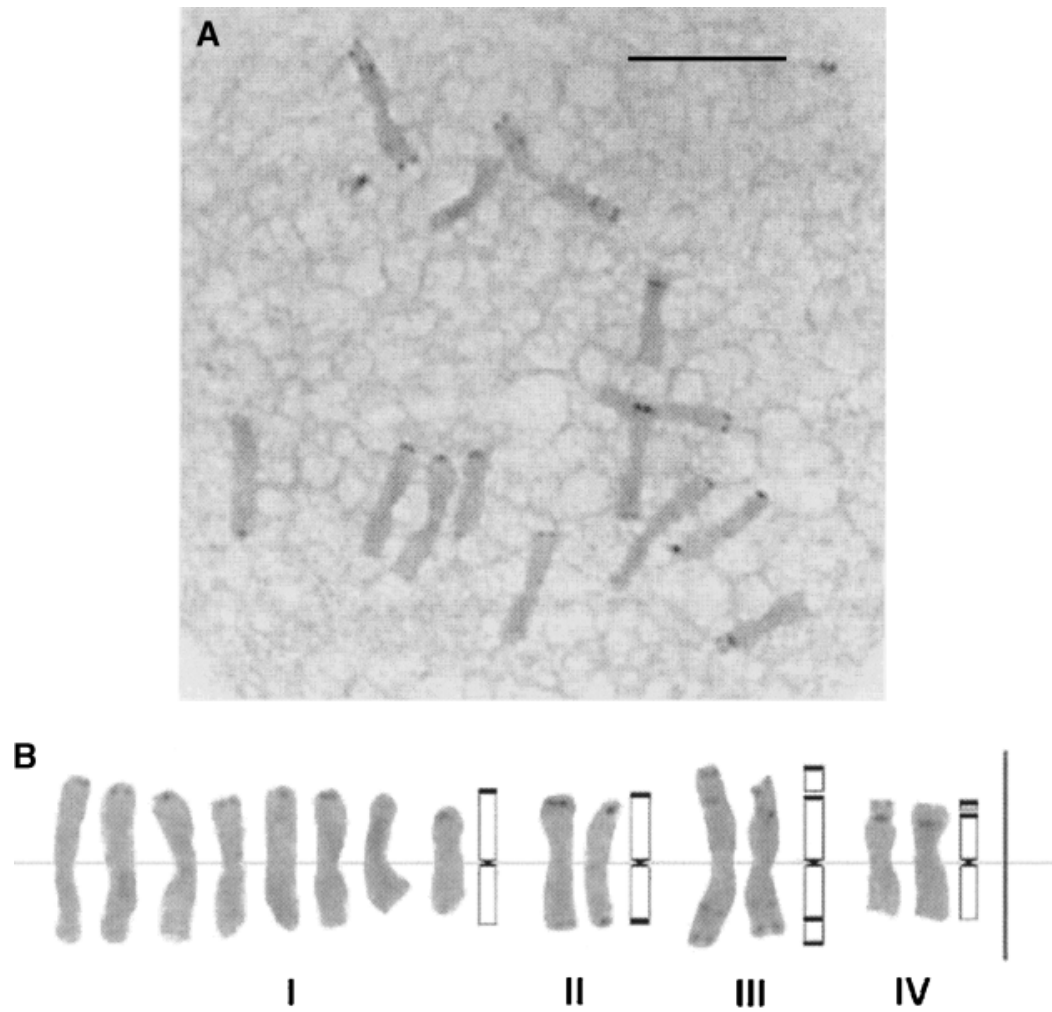

Fig. 1. (A) C-banded mitotic chromosomes of Bromus erectus plant from PGR 4448. (B) C-banded karyotype of B. erectus. Long arms of chromosomes are in upper position. Bar is $10 \mu \mathrm{m}$ in length.

of these chromosomes were placed in the same set (I) (Fig. 2, Table 3).

\section{DISCUSSION}

Nuclear DNA content is characteristic of a species and comparisons of nuclear DNA amounts have proved to be useful in many cytotaxonomic, phylogenetic, and evolutionary studies (Bennett and Leitch, 1995). The analysis of nuclear DNA variation within a genus provides a useful approach to investigating ancestry and genome composition of species included in the genus. Rees and Walters (1965) traced diploid progenitors of cultivated wheats by comparing nuclear DNA contents of diploid wild wheats and cultivated wheats. Based on this study, the $C$ values of cultivated wheats were equal to the sum of their diploid progenitors. The genomic structure of many of the perennial species of the tribe Triticeae has been resolved by using the same approach
(Vogel et al., 1999). However, in the later study, it was found that the DNA content of the alloploid species was significantly smaller than expected on the basis of DNA content of their constituent genomes indicating that DNA was decreased during polyploidization.

Nuclear DNA contents for diploid B. erectus and diploid $B$. variegatus are the first reports for cytotypes of these species. Multiplying the $2 \mathrm{C}$ DNA value of the

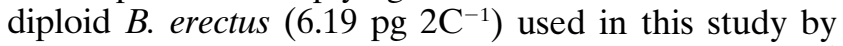
four would give an octaploid DNA level of $24.76 \mathrm{pg} 2 \mathrm{C}^{-1}$ which is larger than the reported value for the octaploid. Multiplying the diploid 2C DNA values of $B$. erectus, $B$. variegatus (6.76 pg $2 \mathrm{C}^{-1}$ ), and B. riparius $\left(6.14 \mathrm{pg} 2 \mathrm{C}^{-1}\right)$ by 2 and 4 would give estimated tetraploid and octaploid values that are significantly larger than the tetraploid

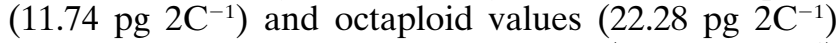

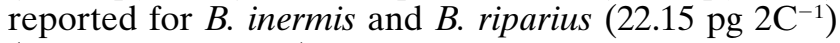
(Tuna et al., 2001b). This nonadditive decrease in genome size during polyploidization in Bromus species

Table 2. The chromosomes of the diploid Bromus erectus.

\begin{tabular}{|c|c|c|c|c|c|c|}
\hline Chromosome set & $\begin{array}{l}\text { Long arm } \\
\text { mean SD }\end{array}$ & $\begin{array}{l}\text { Short arm } \\
\text { mean SD }\end{array}$ & $\begin{array}{c}\text { Total length } \\
\text { mean SD }\end{array}$ & $\begin{array}{l}\text { Satellite size } \\
\text { mean SD }\end{array}$ & $\begin{array}{c}\text { Arm ratio } \dagger \\
\text { mean SD }\end{array}$ & Chromosome type \\
\hline I & $3.76 \pm \mathbf{0 . 2 1}$ & $3.38 \pm \mathbf{0 . 1 5}$ & $7.14 \pm \mathbf{0 . 4 6}$ & & $1.11 \pm \mathbf{0 . 0 5}$ & median \\
\hline II & $3.44 \pm 0.12$ & $3.13 \pm 0.05$ & $6.57 \pm 0.14$ & & $1.09 \pm 0.06$ & median $\ddagger$ \\
\hline III & $4.03 \pm 0.16$ & $2.79 \pm 0.06$ & $8.19 \pm 0.13$ & $1.37 \pm 0.09$ & $\mathbf{1 . 0 3} \pm \mathbf{0 . 0 7}$ & satellite \\
\hline & $3.08 \pm 0.56$ & $2.43 \pm 0.25$ & $6.29 \pm 0.74$ & $\mathbf{0 . 7 8} \pm \mathbf{0 . 0 3}$ & $1.04 \pm 0.08$ & satellite \\
\hline \multicolumn{3}{|c|}{ Total chromosome length } & 99.22 & & & \\
\hline
\end{tabular}

$\dagger$ Arm ratio $=$ (length of the long arm)/(length of the short arm with satellite included in arm length).

$\ddagger$ Median = arm ratio is lower than 1.50 . 


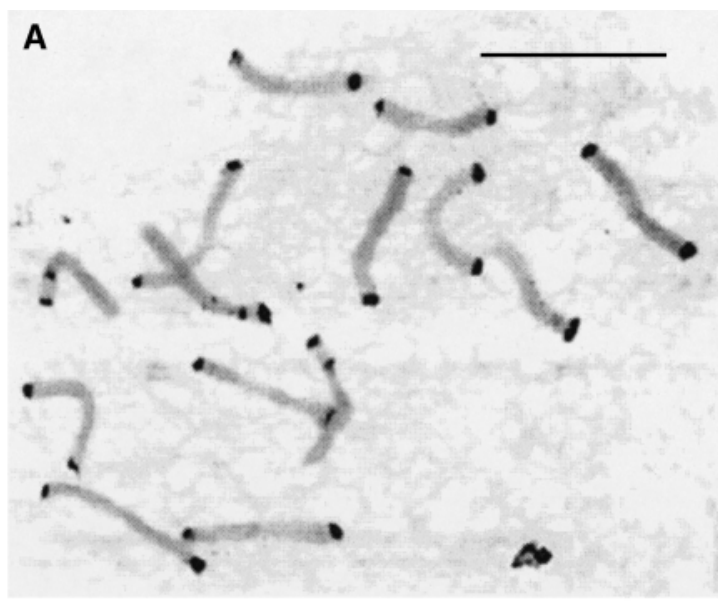

B

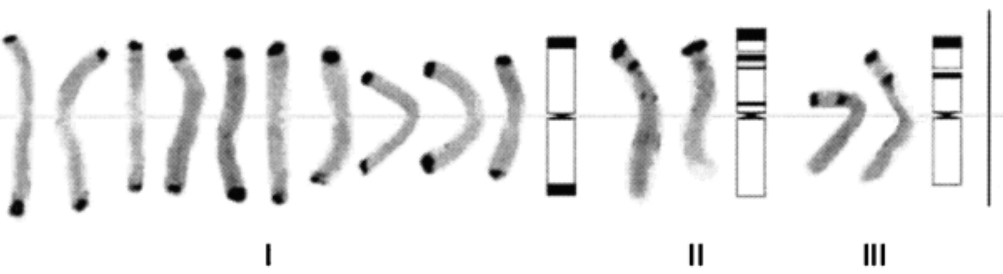

Fig. 2. (A) C-banded mitotic chromosomes of Bromus variegatus plant from PI 315395. (B) C-banded karyotype of B. variegatus. Long arms of chromosomes are in upper position. Bar is $10 \mu \mathrm{m}$ in length.

is in agreement with previous reports on species of Triticeae (Vogel et al., 1999). It is highly probable that loss of DNA may have occurred during the development of the polyploid bromegrasses. However, multiplying the 2C DNA values of diploid $B$. erectus and $B$. variegatus, by 2 would give a much lower 2C DNA values than the reported 2C DNA content of the tetraploid $B$. ciliatus L. (19.13 pg) which is native to North America (Tuna et al., 2005). Based on nuclear DNA content, $B$. ciliatus has a completely different genome than diploid $B$. erectus and $B$. variegatus.

The karyotypes developed in this study are the first C-banded karyotypes for cytotypes of diploid B. erectus and $B$. variegatus. Giemsa C-banding has not been employed in detail to characterize genomes in the genus Bromus. However, all Bromus species analyzed previously had median and submedian chromosomes with similar C-banding patterns consisting mainly of telomeric C-bands (Armstrong, 1991; Kula, 1999; Joachimiak et al., 2001; Tuna et al., 2001a, 2004) except B. ciliatus (Tuna et al., 2005). The karyotypes that are reported in this study are generally in agreement with previous reports on chromosome morphology and banding patterns.
However both diploid species can be distinguished easily from each other by their distinct C-banding patterns. Bromus variegatus had more and larger C-bands than $B$. erectus. The karyotype of another diploid species included in the section Pnigma, B. riparius, (Tuna et al., 2001a) can be distinguished easily from the karyotypes of $B$. erectus and $B$. variegatus by its distinct C-banding pattern. In addition, B. riparius differs from $B$. erectus and $B$. variegatus for the number of chromosomes with satellites. Bromus riparius has only one pair of chromosomes with a satellite while $B$. erectus and $B$. variegatus have two pairs of chromosome with satellites.

Tetraploid $B$. inermis has two pairs of chromosomes with satellites and one of those chromosomes does not have a telomeric C-band on the satellite (Tuna et al., 2004). Octaploid B. inermis has three pairs of chromosomes with satellites, two pair of which have a C-band at the nucleolus organizer region and one pair with a telomeric C-band (Tuna et al., 2004). It has no chromosomes with interstitial C-bands. All satellite chromosomes of $B$. erectus, $B$. variegatus, and $B$. riparius have telomeric C-bands. If the diploids $B$. variegatus and $B$. erectus were the donor species of tetraploid $B$. inermis,

Table 3. The chromosomes of the diploid Bromus variegatus.

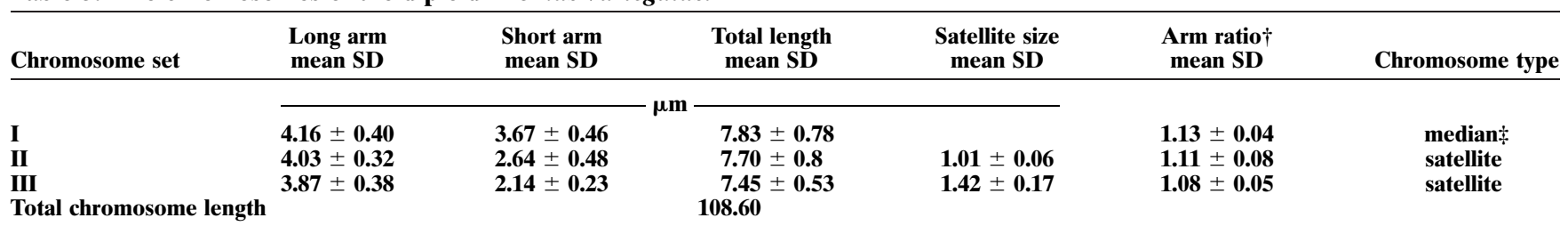

$\dagger$ Arm ratio $=$ (length of the long arm)/(length of the short arm with satellite included in arm length).

$\$$ Median $=$ arm ratio is lower than 1.50 . 
the tetraploid should have four pairs of chromosomes with satellites. The diploid $B$. riparius has one chromosome pair with a telomeric and an interstitial band (Tuna et al., 2001a). A chromosome with this morphology does not exist in the current karyotype of tetraploid or octaploid B. inermis (Tuna et al., 2004).

The number of chromosomes with satellites, the size of the satellites, and the number, size, and location of the C-bands on the chromosomes clearly demonstrate that evolutionary differences have developed among diploid $B$. erectus, $B$. variegatus, and B. riparius. If any one or two of the three diploid species were donor species for tetraploid $B$. inermis, significant evolutionary changes have occurred in the tetraploid $B$. inermis genome since the initial formation of the species. The possible diploid parent species and progeny polyploid species both may have changed via the cytogenetic evolutionary process of duplication, deletion, translocation, and inversion. The evolutionary implications for the octaploid $B$. inermis are the same as for the tetraploid B. inermis. The mechanism for this process in Bromus is currently speculative but in newly synthesized allopolyploid wheats (Aegilops-Triticum spp.) allopolyploid formation was accompanied by extensive genome changes at molecular level, including rapid and nonrandom elimination of specific low-copy DNA sequences, as well as other types of genomic modifications (Ozkan et al., 2001; Shaked et al., 2001). Changes in genome size already existed in the first generation amphiploids, indicating that change was a rapid event (Ozkan et al., 2003).

In summary, the combined use of nuclear DNA content and cytogenetic analysis including the use of Giemsa C-banding in this study and previous studies (Tuna et al., 2001a, 2001b, 2004, 2005) demonstrate that genomes of Eurasian Bromus diploids, B. erectus, B. variegatus, and $B$. riparius are similar but have distinctly different karyotypes. If one or more of these diploids were parent genome donors for tetraploid and octaploid B. inermis, as suggested previously by Armstrong (1991), significant evolutionary changes have occurred in the karyotypes of the diploid or polyploid species or both since the formation of the polyploids. Based on genome size and karyotype comparisons, the genomes of these three Eurasian diploids are distinctly different from genome of tetraploid B. ciliatus.

\section{REFERENCES}

Armstrong, K.C. 1977. Karyotypic models for the A and B genomes of Bromus inermis. Z. pflanzenzuecht. 78:244-252.
Armstrong, K.C. 1979. A and B genome homoeologies in tetraploid and octaploid cytotypes of Bromus inermis. Can. J. Genet. Cytol. 21:65-71.

Armstrong, K.C. 1984. The genomic relationship of the diploid Bromus variegatus to Bromus inermis. Can. J. Genet. Cytol. 26:469-474.

Armstrong, K.C. 1991. Chromosome evolution in Bromus. p. 363-317. In T. Tsuchiya, and T.K. Gupta (ed.) Chromosome engineering in plants: Genetics, breeding, evolution. Part B. Elsevier, Amsterdam, The Netherlands.

Bennett, M.D., and I.J. Leitch. 1995. Nuclear DNA amounts in Angiosperms. Ann. Bot. (London) 76:113-176.

Bennett, M.D., and J.B. Smith. 1976. Nuclear DNA amounts in angiosperms. Philos. Trans. R. Soc. London, Ser. B. 274:227-274.

Falistocco, E., M. Falcinelli, and F. Veronesi. 1995. Karyotype and Cbanding pattern of mitotic chromosomes in alfalfa, Medicago sativa L. Plant Breed. 114:451-453.

Fominaya, A., C. Vega, and E. Ferrer. 1988. Giemsa C-banded karyotypes of Avena species. Genome 30:627-632.

Gill, B.S., and R.G. Sears. 1988. The current status of chromosome analysis in wheat. p. 299-321. In J.P. Gustafson and R. Appels (ed.) Chromosome structure and function. Plenum, New York.

Joachimiak, A., A. Kula, E. Sliwinska, and A. Sobieszczanska. 2001. Cbanding and nuclear DNA amount in six Bromus species. Acta Biologica Cracoviensia Series Botanica 43:105-115.

Kula, A. 1999. Cytogenetic studies in cultivated form of Bromus carinatus (Poaceae). Fragmenta Floristica et Geobotanica Suppl. 7:101-106.

Ozkan, H., A.A. Levy, and M. Feldman. 2001. Allopolyploidy-induced rapid genome evolution in the wheat (Aegilops-Triticum) group. Plant Cell 13:1735-1747.

Ozkan, H., M. Tuna, and K. Arumuganathan. 2003. Nonadditive changes in genome size during allopolyploidization in the wheat (Aegilops-Triticum) group. J. Hered. 94(3):260-264.

Rees, H., and M.R. Walters. 1965. Nuclear DNA and the evolution of wheat. Heredity 20:73-82.

Rychlewski, J. 1970. Karyology of species of the genus Bromus L. Acta Biol. Cracov. (Ser. Bot.) 13:23-35.

Shaked, H., K. Kashkush, H. Ozkan, M. Feldman, and A.A. Levy. 2001. Sequence elimination and cytosine methylation are rapid and reproducible responses of genome to wide hybridization and allopolyplody in wheat. Plant Cell 13:1749-1759.

Steel, R.G.D., and J.H. Torrie. 1960. Statistical methods. 6th ed. Iowa State Univ. Press, Ames, IA.

Tuna, M., K.S. Gill, and K.P. Vogel. 2001a. Karyotype and C-banding pattern of mitotic chromosomes in diploid bromegrass (B. riparius Rehm.). Crop Sci. 41:831-834.

Tuna, M., K.P. Vogel, and K. Arumuganathan. 2005. Genome size and Giemsa C-banded karyotype of tetraploid Bromus ciliatus L. Euphytica 146:177-182.

Tuna, M., K.P. Vogel, K. Arumuganathan, and K.S. Gill. 2001b. DNA contents and ploidy determination of bromegrass germplasm accessions by flow cytometry. Crop Sci. 41:1629-1634.

Tuna, M., K.P. Vogel, K.S. Gill, and K. Arumuganathan. 2004. Cbanding analyses of Bromus inermis genomes. Crop. Sci. 44:31-37.

Vogel, K.P., K.J. Moore, and L.W. Moser. 1996. Bromegrasses. p. 535567. In L.E. Moser, D. Buxton, and M.D. Casler (ed.) Cool-season forage grasses. Agronomy Monograph. ASA, CSSA, SSSA, Madison, WI.

Vogel, K.P., K. Arumuganathan, and K.B. Jensen. 1999. Nuclear DNA content of perennial grasses of the Tribe Triticeae. Crop Sci. 39:661-667. 